\title{
МІКРОЕЛЕМЕНТИ ТКАНИН ОРГАНІЗМУ БДЖІЛ ЗА ПІДГОДІВЛІ НАНОТЕХНОЛОГІЧНИМИ ЦИТРАТАМИ КОБАЛЬТУ I ГЕРМАНІЮ
}

\author{
Ковальчук Ірина Іванівна \\ доктор ветеринарних наук, старший науковий співробітник \\ Львівський національний університет ветеринарної медицини та біотехнологій імені С.З. Ґжицького, \\ м. Львів, Україна \\ ORCID: 0000-0001-9932-6315 \\ irenakovalchuk@ukr.net \\ Кикіш Ігор Богданович \\ аспірант \\ Інститут біології тварин Національної академії аграрних наук України, м. Львів, Україна \\ ORCID: 0000-0002-4311-8346 \\ ihorkykish@gmail.com
}

Федорук Ростислав Степанович

доктор ветеринарних наук, професор, член-кореспондент Національної академії аграрних наук України Інститут біології тварин Національної академії аграрних наук України, м. Львів, Україна

ORCID: 0000-0001-5930-4058

rostislavfedoruk@gmail.com

\begin{abstract}
Цап Марія Михайлівна
кандидат сільськогосподарських наук Інститут біології тварин Національної академії аграрних наук України, м. Львів, Україна

ORCID: 0000-0002-1446-0409 mm_tsap@meta.ua
\end{abstract}

Досліджено вплив нанотехнологічних цитратів кобальту (Зомка/ 300 мл) цукрового сиропу (ц. с.) і германію (60 мке/ 300 мл и. с.), та їхньої суміші у водному розчині на вміст окремих елементів у тканинах різних анатомічних відділів і всього організму бджіл карпатської породи. Сформовано чотири групи бджіл-аналогів: 1) контрольна (300 мл и. с. на бджолосім'ю/ тиждень); 2) дослідна ( 30мка Co/ 300 мл и. с.); 3) дослідна (60мка Ge /300мл и. с.); 4) дослідна (Зомке $\mathrm{Co}+60$ мка $\mathrm{Ge} / 300$ мл и. с.). Бджіл утримували у садках в умовах $30^{\circ} \mathrm{C}$ у лабораторному термостаті впродовж 30 діб із визначенням умісту $\mathrm{Fe}, \mathrm{Co}, \mathrm{Ni}, \mathrm{Cu}, \mathrm{Pb}$ i Cd у гомогенатах тканин голови, грудей, черевия і всього організму. Дослідження мікроелементів проведено на атомно-абсорбиійному спектрофотометрі СФ-115 ПК у сухому мінералізаті гомогенату тканин. Установлено вірогідно вищий уміст феруму у тканинах грудного відділу за дії 60мка германію і суміші цитратів із 30мке Сo та 60мка Ge на тлі вищого рівня кобальту у тканинах бджіл усіх трьох дослідних груп, але нижчого - стосовно свинцю за тенденції до зниження кадмію та нікелю. У тканинах голови бджіл дослідних груп знижувався вміст $\mathrm{Fe}, \mathrm{Ni}, \mathrm{Pb}$ i Cd, a $\mathrm{Cu}-$ тільки у дослідній IV групі із невірогідним підвищенням рівня кобальту. Встановлені зміни у тканинах голови відзначено як для черевця, так і для всього організму бджіл дослідних груп порівняно із контрольною, що вказує на певні фізіологічні особливості кумуляиії і розподілу досліджених мікроелементів у тканинах та органах бджіл у період підгодівлі нанотехнологічними цитратами кобальту і германію. Важливою є виражена детоксикаційна дія нанотехнологічних цитратів кобальту і германію та їхніх сполук, що забезпечує зниження концентрації свинцю, кадмію і нікелю у тканинах як окремих анатомічних відділів бджіл, так і всього організму. Обговорено антагоністичну та синергічну залежність досліджених мікроелементів із іншими мінеральними елементами у фізіологічних процесах живлення бджіл і вмісту у тканинах організму.

Ключові слова: мінеральні елементи, иукровий сироп, тканини, голова, груди і черевце бджіл, нанотехнологічний і атомноабсорбційний методи.

DOI https://doi.org/10.32845/bsnau.vet.2021.3.5

Вступ. Фізіологічна дія мікроелементів у біоорганічних комплексах зумовлена їхньою каталітичною здатністю переводити у збуджений стан електрони всієї біологічної системи (Zoroddu et al., 2019; Kovalchuk et al., 2020; Fu \& Xi, 2020). Такі фрізико-хімічні реакції із участю мікроелементів здатні знижувати енергію активації усієї біологічної системи і дають змогу інтенси- фікувати перебіг фрізіологічних і біохімічних процесів в організмі. Відомо, що мінеральні елементи (Ca, Mg, $\mathrm{Co}, \mathrm{Zn}, \mathrm{Fe}$ та інші) беруть участь у понад 300 біохімічних реакціях і входять до низки ензимів, вітамінів, гормонів як структурні елементи та каталізатори (Zhumadina et al., 2015; Alvarez-Suarez, 2017; Stoika, 2017; Malavolta \& Mocchegiani, 2018; Matuszewska et al., 2021). Водно- 
час доведено, що дефіцит надходження окремих мікроелементів в організм бджіл під час критичних періодів (весняного та осінньо-зимового) їхньої життєдіяльності зумовлює порушення обмінних процесів і знижує стійкість до захворювань (Yang et al., 2017; Kovalchuk et al., 2017). Зокрема, Со і його сполуки підвищують синтез м'язових білків, які виконують важливі функції під час роботи бджіл у період медозбору, стимулює обмінні процеси і їхню продуктивність, яйцекладку бджолиної матки і розвиток бджолиної сімї (Pashajan \& Stolbov, 2008; Fedoruk et al., 2016; Pashchenko, 2018; Yakybchak \& Yermak, 2019). Низький рівень Со у природному кормі бджіл сприяє поширенню низки захворювань, зокрема європейського гнильця, що приносить значні збитки пасічникам (Pashajan \& Stolbov, 2008; Kovalchuk et al., 2020). Водночас сполуки Со відіграють позитивну роль в обмінних процесах. Зокрема, застосування наночастинок Со, одержаних методом нанотехнології, спричинює інтенсифікацію синтезу вітаміну $\mathrm{B}_{12}$ та антиоксидантів у лабораторних тварин (Turko, 2015; Ushkalov \& Turko, 2016). Дослідники вказують на оптимізуючий вплив цієї сполуки Со на протеїновий обмін, розподіл глобулінових фрракцій і підвищення імунобіологічної реактивності організму щурів. Не менш важливе значення у життєдіяльності людини і тварин, у фрізіологічному функціонуванні органів і систем організму відіграють і сполуки $\mathrm{Ge}$, що більше виражено для його рослинних препаратів і БАД. Зокрема, низка досліджень присвячена вивченню впливу препаратів женшеню, що містив різну кількість $\mathrm{Ge}$. Відзначено неоднаковий вплив різних доз $\mathrm{Ge}$ на обмінні процеси і морфометричні показники організму людини і тварин (Lukevich \& Ignatovich, 2003; Dolaychuk et al., 2015; Chunjiang et al., 2015; Li et al., 2017; Cho et al., 2020). Визначали кумулюючу здатність селезінки, нирок, печінки, шлунку, серця і підшлункової залози. Встановлено найвищий вміст $\mathrm{Ge}$ у селезінці, нирках, печінці, легенях, шлунку, серці, підшлунковій залозі. Однак у цих органах щурів контрольної групи концентрація $\mathrm{Ge}$ була дуже низькою (від 0,001 мкг/г до 0,008 мкг/г). Вказано, що не спостерігалося негативного впливу під час додавання женьшеню з великим вмістом $\mathrm{Ge}$ на функцію нирок і їхню гістологію. Маса тіла щурів наближалася до маси контрольної групи, що спростовує думку про затримку $\mathrm{Na}$ та води у тварин під час лікування женьшенем у великих дозах (15-30 г/ 60 кг м.т. людини). Результати цих досліджень не підтверджують зв'язку між концентрацією $\mathrm{Ge}$ у женьшені та нирковою токсичністю. Однак у публікації указується, що харчові добавки, що містять $\mathrm{Ge}$, були вилучені у Великій Британії і заборонені у США через їхній зв'язок із такими захворюваннями, як ниркова недостатність, анемія, нейропатія. В інших країнах органічний $\mathrm{Ge}$, зокрема препарат Bio-Ge, вважається харчовою добавкою $з$ імуномоделюючою дією. Нині біо-германій визнаний новим дієтичним інгредієнтом Управлінням із контролю за продуктами та ліками (FDA) США і віднесений до зеленого списку США. У недавній публікації (Cho et al., 2020) представлено широкий спектр результатів досліджень біологічної дії і клінічних випробувань Bio-Ge, який отримали на основі зброджених дріжджів.
Дослідження авторів підтверджують імуностимулюючу дію Bio-Ge, яка підвищує цитотоксичність клітин кілерів (NK-клітин) та активність імуноглобулінів, уміст В-клітин і фрактору некрозу клітин (TNF). Із урахуванням нових клінічних даних щодо механізму імунностимулюючого впливу $\mathrm{Ge}$ автори вважають, що Bio-Ge є багатообіцяючим терапевтичним засобом і його, безумовно, слід додатково досліджувати для розвитку можливостей імунотерапії.

Важливою $є$ про- та антиоксидантна властивість Bio-Ge, що пояснюється його здатністю знижувати рівень окисного стресу завдяки поглинанню активних форм кисню (АФК) і підтримувати активність глутатіонпероксидази (GSH) на високому рівні. Вказується, що механізм підвищення концентрації GSH у тканинах організму відіграє важливу роль у стимуляції його імунної функції (Cho et al., 2020).

Аналізуючи фізіологічну роль, метаболічний вплив, токсичність Ge та його дефіцит у тварин, інші автори вказують, що сполуки $\mathrm{Ge}$ успішно використовуються у медицині та тваринництві (Li et al.,2017). Розподіл Ge у тканинах та органах тварин коливається від низьких до високих рівнів у нирках, мозку, серці, м'язах, шлунку, легенях, печінці, а також у багатьох ензимах: цитохромоксидазі, карбоангідразі, мітохондріях, хромосомах. Застосування сполук $\mathrm{Ge}$ також базується на його органічних формах разом із амінокислотами (гістидин, метіонін, аланін), органічними кислотами (молочною, лимонною, яблучною тощо) (Lu et al., 1997). Сполуки Ge беруть участь у метаболізмі $\mathrm{O}_{2}$ із використанням здатності до окисного дегідрування та інгібування активних форм кисню. Ge-132 здатний поглинати АФК і запобігти пошкодженню клітин. У цьому огляді літератури автори вказують на виражені антибактеріальні та протигрибкові властивості $\mathrm{Ge}$, проте посилаються на застарілі (80-90 роки) публікації щодо дії Ge-132, які ми не залучаємо до статті. Відзначається також стимулюючий вплив $\mathrm{Ge}-132$, його біотична і колоїдна дія на ріст, розвиток і несучість курей, покращення якості яєць. Органічний Ge посилює функцію відтворення (Nefodova et al., 2019; Kovalchuk et al., 2020) і бере участь у регуляції ендокринної системи, що підтверджують і наші дослідження (Dolaychuk et al., 2015; Fedoruk et al., 2015, $2017,2018)$. Окрім того, важливу біологічну цінність ста-

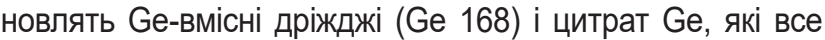
більше застосовуються у тваринництві та ветеринарній медицині (Kaplunenko et al,. 2017; Kovalchuk et al., 2020; Li et al.,2017; Yakubchak \& Yermak, 2019). В іншій роботі встановлено, що органічний германій (Ge-401) може продовжити тривалість життя плодової мушки і підвищити життєдіяльність тварин у разі гіпоксії, але інгібує метаболізм Ca i P (Li et al., 2017), а цитрат Ge суттєво збільшував масу імунних органів (тимусу, селезінки) в мишей і значно підвищував рівень антитіл проти сироваткового гемолізину мишей. Автори огляду стверджують, що Ge-132 потрібний для посилення клітинного захисту організму та його імунної системи.

Отже, дія низьких доз мікроелементів, зокрема у складі нанотехнологічних цитратів, відзначається їхнім регуляторним впливом на окисно-відновні та анаболічно-катаболічні 
процеси в окремих системах, органах, тканинах організму (Kovalchuk et al., 2017; Kaplunenko et al., 2017; DeGrandiHoffman et al., 2018; Pashajan et al., 2021). Однак мінеральне живлення медоносних бджіл і його роль в організмі, а також фрізіологічні зв'язки окремих елементів, таких як Со, $\mathrm{Ge}, \mathrm{Ni}, \mathrm{Cr}$, Cu, Fe i їхніх сполук, одержаних методами нанотехнології у вигляді цитратів, не досить досліджені (Brych et al., 2015; Fedoruk et al., 2016; Kykish et al., 2017; Vlizlo et al., 2018; Kovalchuk et al., 2020). Тому метою дослідження стало вивчення впливу різних доз Сo- і Ge-цитратів нанотехнологічних в умовах їх додавання до цукрового сиропу підгодівлі на вміст деяких мінеральних елементів у тканинах окремих анатомічних відділів і всього організму бджіл.

Матеріал і методи досліджень. Дослідження проведені із використанням чотирьох груп бджолосімей, аналогічних за масою бджіл, силою сім'ї, віком матки, по три сім'ї у кожній групі. Бджоли контрольної (I) групи отримували у весняний період підгодівлю у вигляді 50\% цукрового сиропу (300 мл /сім'ю/ тиждень). Друга група бджіл (дослідна) додатково до 300 мл цукрового сиропу отримувала 30 мкг Со у вигляді цитрату нанотехнологічного. Третя група з 300 мл цукрового сиропу отримувала 60 мкг Ge цитрату нанотехнологічного. Четверта група з 300 мл цукрового сиропу отримувала 30 мкг Со цитрату та 60 мкг Ge цитрату нанотехнологічного. Тривалість випоювання сиропу і цитратів Co i Ge становила 4 тижні. Мікроелементи додавали до цукрового сиропу у вигляді водних розчинів цитратів, отриманих від ТОВ «Наноматеріали і нанотехнології» (м. Київ) (Kosinov \& Kaplunenko, 2009). Для дослідження відбирали зразки тканин цілого організму у 20-25 бджіл та у 30-35 бджіл - із окремих анатомічних відділів (голова, грудний і черевний відділи) з бджолосімей контрольної та дослідних груп. У зразках гомогенатів тканин організму бджіл визначали вміст окремих мікроелементів за допомогою атомно-абсорбційного спектрофотометру СФ-115ПК. Цифрові показники опрацьовані статистично із використанням комп'ютерної програми Microsoft EXCEL із визначенням середніх величин M, їхніх відхилень ( $\pm m)$ і ступеня вірогідності міжгрупових різниць із використанням коефіцієнта Стьюдента (P).

Результати дослідження. Потреба бджіл у макроі мікроелементах забезпечується їхнім надходженням із пилком рослин, водою і нектаром. Додавання до корму бджіл сполук окремих мікроелементів як метаболічних стимуляторів органічного та неорганічного походження, внесених у різних дозах, впливає на корекцію фізіолого-біохімічних процесів і підвищує продуктивність медоносних бджіл. Певний вплив зумовлює також фрізіологічне значення окремих елементів для їхнього організму, оскільки медоносні бджоли здатні селективно нагромаджувати у тканинах організму мікроелементи (Kovalchuk et al., 2020; Zhumadina et al., 2015).

Дослідження вмісту мікроелементів у гомогенаті тканин грудного відділу бджіл вказують на певні відмінності розподілу Fe, Co у цих зразках. Зокрема, вміст Fe був вірогідно нижчим у тканинах грудного відділу бджіл, які отримували 30 мкг Со цитрату, але суттєво перевищував його рівень у зразках бджіл III $(P<0,01)$ i IV $(P<0,05)$ груп (табл. 1).

Концентрація Со виявляла статистично невірогідне підвищення у гомогенатах тканин цього відділу бджіл усіх дослідних груп, що може вказувати на синергічну залежність вмісту цих елементів (Fe-Co-Ge) у тканинах грудного відділу і вищу здатність їх до кумуляції Со. Вплив Со- і $\mathrm{Ge}$-цитратів на вміст $\mathrm{Cu}, \mathrm{Pb}, \mathrm{Cd}$ зберігався на аналогічному рівні і для тканин голови бджіл дослідних груп.

За результатами дослідження встановлено вищі концентрації Со у гомогенаті тканин грудного відділу організму бджіл II, III $(P<0,05)$ i IV $(P<0,01)$ груп (табл.1). Аналіз отриманих результатів дослідження вказує на певні закономірності впливу Co- і Ge-цитратів на вміст досліджених мікроелементів у тканинах окремих анатомічних відділів і всього організму бджіл.

Аналогічні міжгрупові відмінності вмісту Со спостерігали у зразках тканин голови і черевного (крім IV групи) відділу, а також всього організму, проте різниця була не вірогідною.

Встановлено статистично значуще зниження вмісту $\mathrm{Fe}$ i $\mathrm{Pb}$ у гомогенаті тканин грудей, голови, черевця і всього організму бджіл усіх дослідних груп. Дія цих сполук на організм бджіл зумовлювала також невірогідне зниження у тканинах грудного відділу вмісту $\mathrm{Ni} \mathrm{i} \mathrm{Cd}$ порівняно із його рівнем у бджіл контрольної групи. Вміст $\mathrm{Cu}$ у тканинах грудного відділу бджіл, які отримували із цукровим сиропом 30 мкг Co і 60 мкг Ge, зберігався на рівні контролю, проте вірогідно $(p<0,05)$ знижувався у зразках тканин грудей і голови у разі сумісного застосування Co i Ge у IV групі (табл. 1, 2).

Вміст окремих мікроелементів у тканинах грудного відділу організму бджіл

Таблиця 1 за підгодівлі цитратами Сo і $\mathrm{Ge}, \mathrm{мг/кг} \mathrm{(M \pm m,} \mathrm{n}=3)$

\begin{tabular}{|c|c|c|c|c|}
\hline \multirow[b]{2}{*}{$\begin{array}{l}\text { Мікро- } \\
\text { елементи }\end{array}$} & \multicolumn{4}{|c|}{ Групи медоносних бджіл } \\
\hline & $\begin{array}{l}\text { I -контрольна } \\
\text { ЦС }\end{array}$ & $\begin{array}{c}\text { II - дослідна } \\
\text { ЦС + цитрат Со (30 мкг) }\end{array}$ & $\begin{array}{c}\text { III -дослідна } \\
\text { цC + цитрат Ge (60 мкг) }\end{array}$ & $\begin{array}{c}\text { IV-дослідна } \\
\text { цС + цитрат Со(30 мкг)+Ge } \\
\text { (60 мкг) }\end{array}$ \\
\hline $\mathrm{Fe}$ & $37,32 \pm 0,76$ & $30,64 \pm 0,61^{*}$ & $47,12 \pm 0,94^{* * *}$ & $44,35 \pm 0,89^{*}$ \\
\hline Co & $0,54 \pm 0,07$ & $0,79 \pm 0,05^{*}$ & $0,74 \pm 0,03^{*}$ & $0,81 \pm 0,02^{* *}$ \\
\hline $\mathrm{Ni}$ & $1,99 \pm 0,46$ & $1,63 \pm 0,16$ & $1,01 \pm 0,17$ & $1,56 \pm 0,50$ \\
\hline $\mathrm{Cu}$ & $7,34 \pm 0,45$ & $7,53 \pm 1,40$ & $7,45 \pm 2,05$ & $6,02 \pm 0,16^{*}$ \\
\hline $\mathrm{Pb}$ & $1,35 \pm 0,03$ & $1,06 \pm 0,003^{* * *}$ & $1,0 \pm 0,04^{*}$ & $0,86 \pm 0,15^{*}$ \\
\hline $\mathrm{Cd}$ & $0,17 \pm 0,03$ & $0,16 \pm 0,009$ & $0,14 \pm 0,02$ & $0,11 \pm 0,006$ \\
\hline
\end{tabular}


Вміст окремих мікроелементів у тканинах голови медоносних бджіл

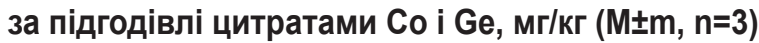

\begin{tabular}{|c|c|c|c|c|}
\hline \multirow{2}{*}{$\begin{array}{c}\text { Мікро- } \\
\text { елементи }\end{array}$} & \multicolumn{4}{|c|}{ Групи медоносних бджіл } \\
\cline { 2 - 5 } & $\begin{array}{c}\text { I -контрольна } \\
\text { ЦС }\end{array}$ & $\begin{array}{c}\text { II - дослідна } \\
\text { цС + цитрат Со (30 мкг) }\end{array}$ & $\begin{array}{c}\text { III - дослідна } \\
\text { цС + цитрат Ge (60 мкг) }\end{array}$ & $\begin{array}{c}\text { IV- дослідна } \\
\text { цС + цитрат Со(30 мкг)+Ge (60 мкг) }\end{array}$ \\
\hline $\mathrm{Fe}$ & $38,41 \pm 0,08$ & $25,57 \pm 0,36^{* * *}$ & $35,60 \pm 2,35$ & $32,05 \pm 0,01^{* * *}$ \\
\hline $\mathrm{Co}$ & $0,62 \pm 0,12$ & $0,75 \pm 0,04$ & $0,71 \pm 0,008$ & $0,67 \pm 0,05$ \\
\hline $\mathrm{Ni}$ & $1,65 \pm 0,22$ & $0,96 \pm 0,01^{*}$ & $1,00 \pm 0,10$ & $0,55 \pm 0,02^{* *}$ \\
\hline $\mathrm{Cu}$ & $6,94 \pm 0,65$ & $6,80 \pm 0,85$ & $6,82 \pm 0,49$ & $5,01 \pm 0,06^{*}$ \\
\hline $\mathrm{Pb}$ & $1,05 \pm 0,04$ & $0,58 \pm 0,05^{* * *}$ & $0,40 \pm 0,04^{* * *}$ & $0,43 \pm 0,02^{* * *}$ \\
\hline $\mathrm{Cd}$ & $0,20 \pm 0,01$ & $0,13 \pm 0,02^{*}$ & $0,10 \pm 0,02$ & $0,15 \pm 0,01^{*}$ \\
\hline
\end{tabular}

Установлені відмінності вмісту досліджених мікроелементів у гомогенаті тканин голови бджіл указують на певні особливості дії застосованих Co- і Ge- цитратів нанотехнологічних щодо кумуляції важких металів у тканинах цього анатомічного відділу. Включення цитратів Co i Ge до цукрового сиропу медоносним бджолам сприяло вірогідному зниженню кількості $\mathrm{Ni}$ у тканинах голови. Вміст $\mathrm{Ni}$ у гомогенаті тканин цього відділу бджіл II дослідної групи знижувався в 1,7 разів $(\mathrm{P}<0,05)$, III - у 1,6 разів і IV - у 2,9 раза $(P<0,01)$ порівняно із контролем.

Водночас спостерігали зниження рівня $\mathrm{Ni}$ у тканинах черевного відділу організму бджіл II, III і IV дослідних груп $(\mathrm{P}<0,001)$ порівняно із контрольною групою. Вплив цитратів Co i Ge характеризувався нижчою концентрацією Cu у тканинах грудей і голови бджіл IV групи $(\mathrm{P}<0,05)$ на тлі вищого рівня у зразках тканин черевного відділу і всього організму бджіл дослідних груп, проте різниці були невірогідні.
Визначення вмісту мікроелементів у тканинах черевного відділу бджіл вказує на раніше відзначену особливість розподілу їх у тканинах голови і грудей. Дія Со i Ge цитрату зумовлювала статистично вірогідне зменшення рівня $\mathrm{Fe} \mathrm{i} \mathrm{Pb} \mathrm{у} \mathrm{тканинах} \mathrm{бджіл} \mathrm{усіх} \mathrm{дослідних} \mathrm{груп,}$ a $\mathrm{Ni}$ - тільки у III і IV групах (табл. 3, 4).

Уміст Со зростав (але невірогідно) у тканинах черевного відділу бджіл II і III, а Cu - у III і IV групах на тлі зниження рівня Cd у бджіл усіх дослідних груп із вірогідністю у тканинах голови II і IV груп порівняно із контролем.

Результати дослідження гомогенатів тканин усього організму вказують на вірогідне зниження вмісту $\mathrm{Fe} \mathrm{i} \mathrm{Pb}$ у зразках тканин бджіл дослідних груп (табл. 4).

Проте концентрація Со у тканинах бджіл дослідних груп статистично вірогідно не перевищувала її рівень у контрольній групі (на відміну від тенденції збільшення у зразках грудного анатомічного відділу). Вміст $\mathrm{Cd}$ у тканинах бджіл усього організму зберігав тенденцію до нижчого рівня у II, III i IV групах, що спостерігається у тканинах грудей і черевця.

Таблиця 3

Вміст окремих мікроелементів у тканинах черевного відділу бджіл

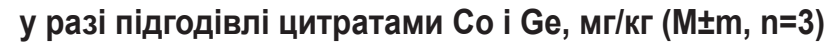

\begin{tabular}{|c|c|c|c|c|}
\hline \multirow{2}{*}{$\begin{array}{l}\text { Мікро- } \\
\text { елементи }\end{array}$} & \multicolumn{4}{|c|}{ Групи медоносних бджіл } \\
\hline & $\begin{array}{l}\text { I -контрольна } \\
\text { ЦС }\end{array}$ & $\begin{array}{c}\text { II - дослідна } \\
\text { цС + цитрат Со (30 мкг) }\end{array}$ & $\begin{array}{c}\text { III - дослідна } \\
\text { цC + цитрат Ge (60 мкг) }\end{array}$ & $\begin{array}{c}\text { IV - дослідна } \\
\text { цС + цитрат Сo(30 мкг)+Ge (60 мкг) }\end{array}$ \\
\hline $\mathrm{Fe}$ & $42,81 \pm 0,58$ & $37,0 \pm 2,52^{*}$ & $30,64 \pm 0,46^{\star \star *}$ & $36,05 \pm 0,45^{\star * *}$ \\
\hline Co & $0,79 \pm 0,10$ & $0,97 \pm 0,08$ & $0,92 \pm 0,02$ & $0,72 \pm 0,08$ \\
\hline $\mathrm{Ni}$ & $2,05 \pm 0,09$ & $1,53 \pm 0,19$ & $1,03 \pm 0,05^{\star * *}$ & $1,03 \pm 0,11^{* * *}$ \\
\hline $\mathrm{Cu}$ & $7,19 \pm 0,12$ & $7,18 \pm 0,57$ & $8,45 \pm 0,69$ & $8,24 \pm 0,65$ \\
\hline $\mathrm{Pb}$ & $1,72 \pm 0,02$ & $0,98 \pm 0,05^{\star * *}$ & $0,85 \pm 0,05^{\star * *}$ & $0,80 \pm 0,08^{* * *}$ \\
\hline $\mathrm{Cd}$ & $0,24 \pm 0,05$ & $0,22 \pm 0,02$ & $0,20 \pm 0,05$ & $0,20 \pm 0,01$ \\
\hline
\end{tabular}

Вміст окремих мікроелементів у тканинах усього організму бджіл під час підгодівлі цитратами Со і $\mathrm{Ge}, \mathrm{мг/кг} \mathrm{(M \pm m,} \mathrm{n=3)}$

\begin{tabular}{|c|c|c|c|c|}
\hline \multirow[b]{2}{*}{$\begin{array}{l}\text { Мікро- } \\
\text { елементи }\end{array}$} & \multicolumn{4}{|c|}{ Групи медоносних бджіл } \\
\hline & $\begin{array}{l}\text { I -контрольна } \\
\text { ЦЦС }\end{array}$ & $\begin{array}{c}\text { II - дослідна } \\
\text { цС + цитрат Со (30 мкг) }\end{array}$ & $\begin{array}{c}\text { III - дослідна } \\
\text { цС + цитрат Ge (60 мкг) }\end{array}$ & $\begin{array}{c}\text { IV- дослідна } \\
\text { цС + цитрат Со(30 мкг)+Ge (60 мкг) }\end{array}$ \\
\hline $\mathrm{Fe}$ & $37,58 \pm 1,02$ & $27,40 \pm 0,03^{* * *}$ & $32,3 \pm 0,91^{* *}$ & $34,00 \pm 0,05^{*}$ \\
\hline Co & $0,54 \pm 0,03$ & $0,69 \pm 0,05$ & $0,61 \pm 0,01$ & $0,57 \pm 0,03$ \\
\hline $\mathrm{Ni}$ & $1,63 \pm 0,07$ & $1,11 \pm 0,07^{\star *}$ & $0,72 \pm 0,04^{* * *}$ & $1,04 \pm 0,09^{*}$ \\
\hline $\mathrm{Cu}$ & $5,48 \pm 0,81$ & $6,44 \pm 0,57$ & $6,10 \pm 0,42$ & $6,21 \pm 0,38$ \\
\hline $\mathrm{Pb}$ & $1,45 \pm 0,02$ & $0,60 \pm 0,01^{* * *}$ & $0,40 \pm 0,03^{* * *}$ & $0,63 \pm 0,01^{* * *}$ \\
\hline $\mathrm{Cd}$ & $0,18 \pm 0,05$ & $0,15 \pm 0,04$ & $0,13 \pm 0,01$ & $0,15 \pm 0,01$ \\
\hline
\end{tabular}


Обговорення. Відсутність статистичної вірогідності щодо вищого вмісту Со у гомогенатах тканин голови бджіл дослідних груп може зумовлюватись анатомічною особливістю будови тканин цього органу і малою дозою застосованого Со цитрату (0,1 мкг/мл ц.с.) під час підгодівлі бджіл, тоді як вищий рівень Со у тканинах грудного відділу бджіл дослідних груп може вказувати на важливу біологічну роль цього ультрамікроелементу для метаболізму грудного анатомічного відділу і підвищення резистентності організму. Встановлено, що додавання 2 мг Со/л цукрового сиропу у період підгодівлі хворих на європейський гнилець бджіл стимулює розвиток мезодермальних зародків личинок і використання ними корму. Характерно, що маса личинок дослідної групи за дії Со була вищою від їхніх аналогів із контрольної групи (Pashajan \& Stolbov, 2008; Kovalchuk et al., 2020). Додавання Со до цукрового сиропу підвищувало морфометричні показники маток і дорослих бджіл порівняно із контрольною групою. У дорослих особин установлено збільшення довжини хоботка, крил і хітинових частинок черевця. У бджіл дослідної групи відзначено кращий розвиток глоткових залоз. Споживання Со у цукровій суміші підвищувало тривалість життя бджіл в умовах утримання їх в ентомологічних садках (Pashajan \& Stolbov, 2008).

У дослідженнях інших авторів (Cebotari et al., 2015) установлено, що підгодівля бджіл біомасою водних мікроводоростей Oocistis borgei Snow (Borgeisnow), багатою макро- і мікроелементами, зокрема Сo i Ge, разом із цукровою пудрою і медом покращує якісний склад маточного молочка, стимулює його виділення бджолами-годувальницями. Вказано на високу біологічну активність мікроводорості завдяки вмісту біодоступних мінеральних елементів, які відіграють каталітичну роль у метаболізмі азотних речовин у робочих бджіл і посилюють оогенез, а також кількість відкладених яєць маткою на 8,3\%. Застосування добавки Borgeisnow підвищувало кількість закритого розплоду на 8,0\%, стійкість бджіл до хвороб - на 3,1 бала (3,5\%), життєздатність розплоду на 1,5 бала, або 1,7\%. В іншій роботі цих авторів указується, що весняна підгодівля бджіл цукровим сиропом, збагаченим водним розчином органічної сполуки (гетероядерним координаційним сульфратом [трис-тіосемикарбазид кобальту (III )] [Co (tios) 3] і [1,2-діаміноциклогексантетраацетат вісмуту (III)] гексагідрат - , [Bi $(\mathrm{CDTA})] \mathrm{SO} 46 \mathrm{H}_{2} \mathrm{O}$ ) у водному розчині із концентрацією 1 мг\% протягом 3 тижнів, стимулювала життєдіяльність бджолиних сімей. Застосування цих сполук характеризувалося збільшенням закритого розплоду на $3,9 \%$, його резистентності - на 2,2\% і продуктивності бджолиних сімей (Cebotari et al,. 2015 a). Вказується, що яйцекладка бджолиних маток у сім'ях, яким згодовували зазначені добавки Со i Bi, була у 1,9 разів вищою у першому періоді досліджень, ніж у сімей, які отримували екстракт біомаси Apispir+Fe+Se, або на 9,7\% за весь період застосування добавки порівняно із контрольною групою.

Дослідженнями багатоелементного мінерального складу бджолиного обніжжя, прополісу і маточного молочка у західному регіоні Польщі встановлено різні рівні макро- і мікроелементів у продукції бджіл. Зважаючи на те, що вміст мінеральних елементів, зокрема Со і $\mathrm{Ge}$, залежить від фракторів навколишнього середовища, автори вказують на необхідність розробити нормативні стандарти їхнього вмісту у продукції бджільництва (Matuszewska et al., 2021). Водночас відзначено низький уміст Со $(0,04)$ у пилку (бджолине обніжжя), нижчий від його рівня у прополісі $(0,12)$. Низький рівень Со відзначено також у маточному молочку (0,003 мг/кг), що може вказувати на недостатній рівень забезпечення цим ультрамікроелементом бджолиних сімей у цьому регіоні Польщі.

У механізмі впливу Ge на імунітет переважно беруть участь імунні органи, їхні клітини (такі як NK-клітиникілери, дендритні клітини, макрофраги, Т-клітини і В-клітини), антитіла, або імуноглобуліни, і цитокіни. Механізми можуть відноситися до окислювальної функції, оскільки германій бере участь у регуляції ліпідного обміну або метаболізмі кисню (Lu et al., 1997; Niu et al., 2021; Lukevich \& Ignatovich, 2003; Cho et al., 2020). Однак у публікаціях інших дослідників указується на відсутність впливу введеного додатково органічного германію на ріст імунних органів у курчат-бройлерів на різних стадіях вирощування (Niu et al., 2001). Органічна сполука Ge-201 також не змінювала показники тимуса та індекс селезінки у мишей (Li et al., 2017).

У публікації (Cho et al., 2020) аналізується гіпотеза про визначальну роль клітин-кілерів (NK- клітин) в імуностимулюючому механізмі органічного $\mathrm{Ge}$, що визначається підвищеною цитотоксичністю NK-клітин. Окрім того, вказується, що імуностимулюючі властивості органічного $\mathrm{Ge}$ посилюються шляхом збагачення тканин $\mathrm{O}_{2}$, детоксикації елементів окремих важких металів, поглинання активних форм кисню і підвищення рівня глутатіону. Поглинаючу функцію органічного Ge щодо шкідливих метаболічних компонентів відзначено на різних типах АФК, зокрема перекису водню, супероксидного аніону, гідроксильного радикалу. Вказується, що здатність органічного Ge до поглинання АФК і підвищення концентрації глутатіону у тканинах можна вважати основним механізмом його імуностимулюючої функції.

Активація функції NK- клітин підвищує рівень IgG1, який $€$ основним у розпізнаванні, нейтралізації та елімінації патогенів і токсичних антигенів. Спорідненість lgG1 до цих антигенів використовується для посилення ефекторних функцій імунітету. Дослідники відзначають, що Bio-Ge $€$ перспективним терапевтичним засобом для імунотерапії, а його імуностимулюючий ефект може формувати новий розвиток вивчення терапевтичної дії цього препарату. Проведено рандомізовані дослідження із подвійним сліпим плацебо на 130 особах із визначенням токсикологічних, антропометричних, біохімічних (кров, сеча) показників, активності природних клітин-кілерів, цитокінів та імуноглобулінів (Cho et al., 2020). Bio-Ge застосовували пацієнтам у дозі 1,2 г/добу протягом 3 тижнів у вигляді 4 капсул (по 2 зранку і ввечері). Дію Bio-Ge підтверджено його застосуванням протягом більше 20 років і доведено ефективність як імуностимулятора, що підвищує цитотоксичність NK-клітин, активує синтез імуноглобулінів, В-клітин; він є фрактором некрозу пухлин (TNF)- d для людей. Вio-Ge одержано із дріжджів 
Saccharomyces cerevisiae від Корейського НДІ біонаук та біотехнології Gene Bank.

У наших дослідженнях відзначено важливу роль Со і $\mathrm{Ge}$ у зниженні вмісту важких металів (Pb, Cd, Ni) в окремих анатомічних відділах і тканинах усього організму бджіл дослідних груп, що вказує на детоксикаційну фрункцію нанотехнологічних цитратів Co i $\mathrm{Ge}$. У літературі містяться результати досліджень щодо такого впливу інших мікроелементів та їхніх сполук, зокрема Se. Більшу тривалість життя (20,9 днів) мали бджоли, які отримували цукровий сироп із селен-активом у дозі 0,25 мг/кг. У контрольній групі, яка отримувала цукровий сироп у чистому вигляді, тривалість життя становила 17,2 дня (Pashajan et al., 2021). Автори рекомендують застосовувати добавки селен-активу із цукровим сиропом у кількості 0,25 мг/кг задля підвищення стійкості бджіл до екологічно несприятливих умов середовища та очищення їхнього організму від полютантів.

Аналіз літературних джерел свідчить, що надходження мінеральних елементів в організм бджіл із природніх і штучних кормів (нектару, меду, пилку, цукрового сиропу) суттєво впливає на вміст мікроелементів як у тканинах, так і у продукції бджіл та інших видів тварин.

Зокрема, згодовування із кормом лабораторним щурам Со у вигляді мінеральної сполуки (0,1 мкг/кг м. т. з $\left.\mathrm{CoCl}_{2}\right)$ і нанодисперсної фрорми у вигляді наночастинок (н.ч.) (0,1 мг і 1 мг Со/кг маси тіла) впродовж 90 діб зумовлювало посилення інтенсивності перекисного окиснення ліпідів за дії вищої дози Со у мг/кг маси тіла (Turko, 2015; Ushkalov \& Turko, 2016). У крові тварин, яким застосували 1 мг Со/кг маси тіла, встановлено вірогідно вищий уміст дієнових кон'югатів і малонового диальдегіду. Однак інтенсивність окиснювальної модифікації білків мембранних фракцій, визначених за утворенням нейтральних та основних карбонільних похідних, вірогідно не змінювалася порівняно із їхніми величинами у крові щурів контрольної і дослідних $\left(0,1 \mathrm{~m} /\right.$ кг маси тіла з $\mathrm{CoCl}_{2}$ і н.ч. Со) груп (Ushkalov \& Turko, 2016). Автори роблять висновок про біосумісність і біотичність наночастинок Со у дозі 0,1 мг/кг маси тіла та можливу її адаптогенну дію порівняно з іншими застосованими дозами.

Дослідженнями сезонної особливості рівня вмісту металів у тканинах організму бджіл із територій різного техногеного навантаження встановлено вищий вміст $\mathrm{Cd}$ у 3,3, Pb-4,5 i Mn (у 2,3 рази порівняно із контролем). Не виявлено розбіжностей щодо концентрації ВМ у тканинах бджіл контрольної групи з умовно забрудненої території у літній та осінній періоди їх життєдіяльності (Bilalov et al., 2015). Проте вміст Pb, Cd, Cu у тканинах бджіл із території у 30-кілометровій зоні розміщення промислових підприємств та автошляхів був вищим. Дослідження зразків меду із різних континентів щодо вмісту мінеральних елементів указують на суттєві відмінності їхньої концентрації, що визначається інтенсивністю екологічного забруднення навколишнього середовища (Solayman et al., 2016). Показано, що загальна концентрація всіх мінералів у меді може коливатися від 0,1\% до 0,2\% нектарного меду. Проведений авторами цієї публікації аналіз доступних літературних джерел за 2000-2014 роки свідчить про збільшення верхньої межі коливання вмісту мікроелементів від 0,11\% до 0,72\%. Уміст Со становив 172 мкг/кг із коливанням від 0,01 до 300 мкг/кг. Відзначено можливість використання меду як індикатора вмісту мікроелементів і ВМ в екологічних об'єктах навколишнього середовища Великої Британії.

Висновки. Підгодівля медоносних бджіл цукровим сиропом із додаванням нанотехнологічних цитратів Со і Ge упродовж 30 діб в умовах термостату зумовлює зміну вмісту $\mathrm{Co}, \mathrm{Fe}, \mathrm{Ni}, \mathrm{Cu}, \mathrm{Pb}, \mathrm{Cd}$ у тканинах усього організму та його анатомічних відділів - голови, грудей, черевця.

Застосування цитратів Co i Ge характеризувалося підвищенням ( $\mathrm{P}<0,05 ; \mathrm{P}<0,01)$ умісту Со і зниженням Fe $(P<0,05 ; P<0,01)$ та $\mathrm{Pb}(\mathrm{P}<0,01 ; \mathrm{P}<0,05)$ у тканинах грудного відділу бджіл дослідних груп як за окремого, так і сумісного їх згодовування. Вірогідно нижчими є рівні Fe i $\mathrm{Pb}$, установлені у тканинах голови, черевця і всього організму бджіл дослідних груп, що вказує на антагоністичний зв'язок цих елементів у тканинах із надходженням мікродоз нанотехнологічних цитратів Co і $\mathrm{Ge}$.

Дія Co i Ge в організмі бджіл зумовлювала вірогідне зниження вмісту й інших мікроелементів у тканинах усього організму, зокрема $\mathrm{Ni}(\mathrm{P}<0,05-\mathrm{P}<0,001)$ та його окремих анатомічних відділів - голови (Ni та $\mathrm{Cd}$ $\mathrm{P}<0,05 ; \mathrm{P}<0,05 ; \mathrm{Cu}, \mathrm{P}<0,05)$, черевця $(\mathrm{Ni}, \mathrm{P}<0,001)$, що може свідчити про детоксикаційну та інгібуючу здатність застосованих доз нанотехнологічних цитратів Co i $\mathrm{Ge}$ щодо цих мікроелементів як важких металів.

\section{Бібліографічні посилання:}

1. Alvarez-Suarez, J. M. (2017). Bee Products-Chemical and Biological Properties. Springer International Publishing: New York, USA, 1-306.

2. Bilalov, F., Skrebneva, L., Nikitin, O., Shuralev, E., \& Mukminov M. (2015). Seasonal Variation in HeavyMetal Accumulation in Honey Bees as an Indicator of Environmental Pollution. Research Journal of Pharmaceutical, Biological and Chemical Sciences, 6(4), 215-221.

3. Brych, O. I., Synetar, E. O., \& Kaplunenko, V. H. (2015). Perspektyvy zastosuvannia nanoakvakhelativ metaliv [Metals nanoaquahelates prospects usage]. Dosiahnennia biolohii ta medytsyny, 2(26), 64-66 [in Ukrainian].

4. Cebotari, V., Buzu, I., Gliga, O., \& Postolachi, O. (2015). New nutritional supplements for bees during deficient harvesting period. Scientific Papers-Animal Science Series: Lucrări Ştiinţifice - Seria Zootehnie, 67, 73-80.

5. Cebotari, V., Buzu, I., \& Toderaş, I. (2015a). Influence of some organic coordination compounds containing Co and $\mathrm{Bi}$ on development morph-productive characters of the bee families. International Conference of University of Agronomic Sciences and Veterinary Medicine of Bucharest. Faculty of Animal Science. Scientific papers, Series D. Animal Science, Volume LVIII Ed. „Ceres”, România, Bucharest, 181-188.

6. Cho, J. M., Chae, J., Jeong, S. R., Moon, M. J., Shin, D. Y., \& Lee, J. H. (2020). Immune activation of Bio-Germanium in a randomized, double-blind, placebocontrolled clinical trial with 130 human subjects: Therapeutic opportunities from new insights. PloS one, 15(10). doi:10.1371/journal.pone.0240358. 
7. Chunjiang, T., Lu, X., \& Wenlie C. (2015). Germanium in ginseng is low and causes no sodium and water retention or renal toxicity in the diuretic-resistant rats. Experimental Biology and Medicine, 240(11), 1505-1512.

8. DeGrandi-Hoffman, G., Gage, S. L, Corby-Harris, V., Carroll, M., Chambers, M., \& Graham, H. (2018). Connecting the nutrient composition of seasonal pollens with changing nutritional needs of honey bee (Apis mellifera L.) colonies. Journal Insect. Physiology, 09, 114-124.

9. Dolaychuk, O. P., Fedoruk, R. S., Kovalchuk, I. I., \& Kropyvka, S. I. (2015). Physiological and biochemical processes in the organisms of rats when feeding them with different amounts of germanium citrate. Biolohiia tvaryn, 17(2), 50-56 [in Ukrainian].

10. Fedoruk, R. S., Dolaychuk, O. P., Kovalchuk, I. I., \& Tsap, M. M. (2015). Reactions of physiological systems rats' organism by watering them low and high doses Germanium «nanoaquacitrate». Agriculture science and practice, 2(3), 15-21 [in Ukrainian].

11. Fedoruk, R. S., Tesarivska, U. I., Khrabko, M. I., \& Tsap, M.M. (2017). Growth and development of the organism and immunophysiological indices of blood of mail $F_{2}$ rats, affected by different doses of nanogermanium citrate. Agricultural Science and Practice, 4(2), 14-22 [in Ukrainian].

12. Fedoruk, R. S., Tesarivska, U. I., Khrabko, M. I., Tsap, M. M., \& Denys, G. G. (2018). Influence of dispensing different doses of germanium citrate on the content of trace elements in tissues and organs of male rats $\mathrm{F}_{2}$. Agricultural Science and Practice, 5(3), 40-46 [in Ukrainian].

13. Fedoruk, R. S., Pashhenko, A. G., Koval'chuk, I. I., \& Romaniv, L. I. (2016). Intensivnost' otkladyvanija jaic pchelinymi matkami v vesennij period pri skarmlivanii in sem'jam citratov Co i Ni s saharnym siropom [Intensity of laying eggs by queen bees in spring when feeding $\mathrm{Co}$ and Ni citrates with sugar syrup to their families]. Sollection of works of scientific symposium with international participation ,Zootechnycal science - an important factor for the european type of the agriculture". Maximovca, 774-779 [in Russian].

14. Fu, Z., \& Xi, S. (2020). The effects of heavy metals on human metabolism. Toxicol. Mech. Methods, 30, 167-176.

15. Kaplunenko, V. H., Fedoruk, R. S., Kovalchuk, I. I., Pashchenko, A. H., Romaniv, L. I., Dvyliuk, I. I., \& Kykish, I. B. (2017). Biologic action of citrates of the microelements in melliferous bees in different periods of their lives. Journal of Trace Elements in Medicine and Biology, 41(S1), 64.

16. Kovalchuk, I. I., Kykish, I. B., \& Kaplunenko, V. H. (2020). Vplyv tsytrativ mikroelementiv na reproduktyvnu zdatnist bdzholynykh matok [Actual problems of natural sciences: modern scientific discussions] : Collective monograph. Riga, Latvia : "Baltija Publishing", 87-110.

17. Kovalchuk, I. I., Kaplunenko, V. G., Pashchenko, A. G., Dvylyuk, I. I., \& Kykish, I. B. (2017). Trace elements of bees tissues after feeding by citrate-based mineral and hydrocarbon complexes. 33 Joint Annual Meeting of the German Society for Minerals and Trace Elements (GMS) with Zinc-UK «Zinc and other Transition Metals in Health and Disease», 35.

18. Kykish, I. B., Koval'chuk, I. I. \& Romaniv L. I. (2017). Vlijanie raznyh doz mikrojelementnogo preparata na vyzhivaemost' medonosnyh pchel [Influence of different doses of a microelement preparation on the survival of honey bees]. Sovremennye problemy veterinarnoj patologii i biotehnologii v agropromyshlennom komplekse: materialy Mezhdunarodnoj nauchno-prakticheskoj konferencii, posvjashhennoj 95-letiju RUP «Institut jeksperemental'noj veterinarii imeni S. N. Vyshelesskogo», Minsk, 16-17 November, 321-324 [in Russian]

19. Li, L., Ruan, T., Lyu, Y. \& Wu, B. (2017). Advances in Effect of Germanium or Germanium Compounds on Animals. Journal of Biosciences and Medicines, 05, 56-73. doi:10.4236/jbm.2017.57006.

20. Lu, S. L., Tang, J. X. \& Deng, L. S. (1997). Effects of Germanium Citrate on the Immunogenic Function of Mice. Guangdong Trace Elements Science, 4, 21-23.

21. Lukevics, E. \& Ignatovich, L. (2003). Biological Activity of Organogermanium Compounds. Cheminform, 34, $279-295$.

22. Malavolta, M., \& Mocchegiani, E. (2018). Trace elements and minerals in Health and Longevity. Part of the Healthy Ageing and Longevity book series (series ed. Suresh I. S. Rattan), 8, 328.

23. Matuszewska, E., Klupczynska, A., Maciotek, K. Kokot, Z. I., \& Matysiak J. (2021). Multielemental Analysis of Bee Pollen, Propolis, and Royal Jelly Collected in West-Central Poland. Molecules, 26(9), 2415. doi.org/10.3390/ molecules 26092415

24. Nefodova, O. O., Halperin, O. I., \& Shatorna, V. F. (2019). The influence of cerium and germanium citrates on the process of embryogenesis of rat on the background of cadmium intoxication. Bulletin of problems biology and medicine, 1(1), (148), 273-278. doi:10.29254/2077-4214-2019-1-1-148-273-278.

25. Niu, Z. Y., Liu, F. Z., Wan, Y. S., Liang, X. \& Xie, M. (2001). Effects of Germanium on the Growth of Main Immune Organs in Broilers. Journal of Northwest A \& F University (Natural Science Edition), 10, 41-43.

26. Pashajan, A. S., Stolbov, N. M. (2008). Kormovye dobavki dlja pchel. Pchelovodstvo [Feed additives for bees. Apiculture], 7, 14-15 [in Russian].

27. Pashajan, S. A., Sidorova, K. A., \& Jurina, T. A. (2021). Nekotorye voprosy povyshenija zhiznestojkosti pchel v uslovijah tehnogeneza [Optimization of viability indicators of bees under technogenesis conditions]. Vestnik Kras.GAU, (3), 88-92. DOI: 10.367181819/4036-2021-3-88-92 [in Russian].

28. Kosinov M. V., Kaplunenko V. H. Pat. 38391 UA, MPK C 07 C 51/41 Sposib otrymannia karboksylativ metaliv. Nanotekhnolohiia otrymannia karboksylativ metaliv [Method for metal carboxylates obtaining. Nanotechnology of obtaining metal carboxylates]. Opubl. 12.01.2009, Biul. № 1 [in Ukrainian].

29. Solayman, M., Islam, M. A, Paul, S., Ali Y., Khalil, M. I., Alam, N. \& Gan, S. H. (2016). Physicochemical Properties, Minerals, Trace Elements, and Heavy Metals in Honey of Different Origins, 15, 119-233. doi.org/10.1111/1541-4337.12182

30. Stoika, R. S. (2017). Bahatofunktsionalni nanomaterialy dlia biolohii i medytsyny: molekuliarnyi dyzain, syntez i zastosuvannia [Multifunctional nanomaterias for biology and medicine: molecular design, synthesis and application]. «Naukova dumka»: Kyiv, 363 [in Ukrainian]. 
31. Turko, Ya. I. (2015). Vplyv nanokobaltu na antyokysliuvalnoi systemy orhanizmu shchuriv za hostroho toksykolohichnoho eksperymentu [Influence of nanocobalt on antioxidant system of rats by acute incisive experiment]. Naukovyi visnyk Lvivskoho natsionalnoho universytetu veterynarnoi medytsyny ta biotekhnolohii imeni Z. S, Hzhytskoho, 17, 1(61), 194-200 [in Ukrainian].

32. Ushkalov, V. O., \& Turko, Ya. I. (2016). Stan antyokysliuvalnoi systemy orhanizmu shchuriv za dii nanokobaltu $\mathrm{v}$ khronichnomu toksykolohichnomu eksperymenti [Antioxidant system state of the rats organism at action of nanocobalt in chronic toxicological experiment]. Naukovyi visnyk Lvivskoho natsionalnoho universytetu veterynarnoi medytsyny ta biotekhnolohii imeni S. Z. Gzhytskoho, 18 (1, 65), 238-243 [in Ukrainian].

33. Vlizlo, V. V., Fedoruk R. S., \& Iskra R.Ya. (2018). Biolohichna diia funktsionalnykh nanomaterialiv u riznykh vydiv tvaryn [Biological effect of functional nano-materials in various species of animals]. Visnyk Ahrarnoi Nauky, 96(11), 80-86 [in Ukrainian]

34. Yakubchak, O. M. \& Yermak A. V. (2019). Vplyv hermaniiu tsytratu na pokaznyky yakosti ta bezpechnosti medu naturalnoho [The influence of hermanium citrate on the indicators of quality and safety of natural honey] Naukovi dopovidi NUBIP Ukrainy, 2(78), 1-9 [in Ukrainian].

35. Yang, W., Tian, Y., Han, M. \& Miao, X. (2017). Longevity extension of worker honey bees (Apis mellifera) by royal jelly optimaldose and active ingredient, 5, 3118; DOI 10.7717/peerj.3118.

36. Zhumadina, Sh. M., Kalashnikova, M. V., Sidorova, K. A., \& Pashajan, S. A. (2015). Osobennosti morfofunkcional'noj izmenchivosti pchel [Features of morphofunctional variability of bees]. Pavlodar, Kereku, 150 [in Russian].

37. Zoroddu, M. A., Aaseth, J., Crisponi, G., Medici, S., Peana, M. \& Nurchi, V. M. (2019). The essential metals for humans: A brief overview. J. Inorg. Biochem., 195, 120-129.

Kovalchuk I. I., Doctor of Veterinary Sciences, Senior Research Fellow, Lviv National Stepan Gzhytsky University of Veterinary Medicine and Biotechnology, Lviv, Ukraine

Kykish I. B., Ph.D. student, Institute of Animal Biology of the National Academy of Agrarian Sciences, Lviv, Ukraine

Fedoruk R. S., Doctor of Veterinary Sciences, Profesor, Member of the NAAS, Institute of Animal Biology of the National Academy of Agrarian Sciences, Lviv, Ukraine

Tsap M. M., Master of Agriculture, Institute of Animal Biology of the National Academy of Agrarian Sciences, Lviv, Ukraine

\section{Microelements of bee tissues for feeding with nanotechnological cobalt and germanium citrates}

We examined the effect of nanotechnological citrates of Cobalt (30 $\mu \mathrm{g} / 300 \mathrm{ml})$, sugar syrup (s.c.) and Germanium $(60 \mu \mathrm{g} / 300 \mathrm{ml} \mathrm{s.c.})$, and their mixture in aqueous solution on the content of individual elements in tissues of various anatomical regions and the whole body of the Carpathian bee. Four bee-analog groups were formed, control group (I) $300 \mathrm{ml}$ s.C. per bee family/week, study group II (30 $\mathrm{mg}$ Coe/300 ml s.c.), study group III (60 $\mu \mathrm{g} \mathrm{Ge/300} \mathrm{ml} \mathrm{s.c.),} \mathrm{and} \mathrm{study} \mathrm{group} \mathrm{IV}$ (30 $\mu \mathrm{g}$ Coe $+60 \mu t \mathrm{Ge} / 300 \mathrm{ml} \mathrm{s.c.)}$. Bees were kept in gardens under 30 degrees in a laboratory thermostat for 30 days determining the content of $\mathrm{Fe}, \mathrm{Co}, \mathrm{Ni}, \mathrm{Cu}, \mathrm{Pb}$ i $\mathrm{Cd}$ in homogenates of head, breast, abdomen and whole body tissues. The microelements study was carried out using atomic absorption spectrophotometer SF-115 PC, in dry mineralizate of tissue homogenate. It was found probably the highest Ge content in the tissues of the thoracic section because of the effect of $60 \mu \mathrm{g}$ Germanium and a citrate mixture with $30 \mu \mathrm{g}$ Co and $60 \mu \mathrm{g} \mathrm{Ge}$, against the background of the highest level of Cobalt in the tissues of all three study groups, but the lowest Lead for the tendency to decrease Cadmium and Nickel. The content of $\mathrm{Fe}, \mathrm{Ni}, \mathrm{Pb} \mathrm{i} \mathrm{Cd}$, and $\mathrm{Cu}$ was reduced in the head tissues of bees of the study groups, only in the group IV there was an unlikely increase in Cobalt. There were established changes both in tissues of the head, abdomen and the whole organism of bees of the study groups compared to the control group, indicating certain physiological features of cumulation and distribution of the studied microelements in tissues and organs of bees during feeding with Cobalt and Germanium nanotechnology citrates. Of importance is the pronounced detoxifying effect of nanotechnological Cobalt and Germanium citrates and their combination, which provides a reduction in the concentration of Lead, Cadmium and Nickel in the tissues of both individual anatomical regions of bees and the whole organism. The antagonistic and synergistic dependence of the studied microelements in physiological processes and content in tissues of the body with other mineral elements of bee nutrition is discussed.

Key words: mineral elements, sugar syrup, chest and abdomen of bees, bee tissues, nanotechnological and atomic absorption methods. 